\title{
Production and Characterization of Crop Residues Derived Biochars for Soil Amendment and Carbon Sequestration
}

\author{
Désiré Jean-Pascal Lompo (Corresponding Author) \\ Université de Dédougou (UDDG), BP 176, Dédougou, Burkina Faso, Phone number : +226 \\ 702787 58; E-mail: lompodesire@yahoo.fr
}

\begin{abstract}
Lambiénou Yé
Université de Dédougou (UDDG), BP 176, Dédougou, Burkina Faso.

E-mail: ylambienou@yahoo.fr
\end{abstract}

Souleymane Ouédraogo

Institut de l'environnement et de recherches agricoles/ Centre régional de recherches environnementale et agricole (INERA/CRREA) de l'Ouest, Station de Farako-Bâ, 01 BP 910

Bobo-Dioulasso 01, Burkina Faso. E-mail: osilamana@ yahoo.fr

Siélé Ibrahima Sori

Bureau national des sols (BUNASOLs), Ouagadougou, Burkina Faso, 03 BP 7005

Ouagadougou 03, Burkina Faso; E-mail: ibrahim_sori@yahoo.fr

\section{Hassan Bismark Nacro}

Université Nazi BONI (UNB) de Bobo-Dioulasso, Laboratoire d'étude et de recherche sur la fertilité du sol (LERF), BP 1091- Bobo Dioulasso, Burkina Faso; E-mail: nacrohb@yahoo.fr

Received: Oct. 28, 2020

doi:10.5296/jas.v9i1.17890
Accepted: Dec. 2, 2020

Published: Dec. 10, 2020

URL: https://doi.org/10.5296/jas.v9i1.17890

\section{Abstract}

This study focused on the production and characterization of biochars from three types of 
crop residues comprising cotton stems, corn cobs and sorghum stems. The reactor used was a local cone kiln made from a 200-liter drum. The production parameters measured included the duration of pyrolysis, the amount of biochar produced and the production yield. The chemical characteristics of the biochars were determined using the usual analytical methods used for organic amendment analyses. According to the study, pyrolysis time, biochar quantities and production yields depended on the type of crop residues. The three types of biochar obtained showed high $\mathrm{C} / \mathrm{N}$ values indicating that their use as soil amendment must be combined with mineral fertilizers to ensure good plant development and crop yield. The heavy metal contents of the three biochar types complied with the international standards recommended for biochars by the International Biochar Initiative (IBI) and by the European Biochar Certificate (EBC). The production and the use of Biochar from crop residues is an interesting alternative for sustainable soil fertility management in the Sahelian countries.

Keywords: soil fertility, organic amendment, biochar, crop residues, pyrolysis

\section{Introduction}

Soil fertility management in sub-Saharan African countries such as Burkina Faso remains one of the major concerns for agricultural development (Bikienga, 2002). In fact, the low level of agricultural production and the food security problems in this part of the world can be explained by the low level of soil fertility and its continuous decline due to both natural and anthropogenic factors (Yanggen et al, 1998). In response to this situation, national and international agricultural research centers have carried out numerous studies to understand and improve soil management and rehabilitation in these countries (Kumwenda et al, 1996). Several recommendations such as the application of organic amendments and mineral fertilizers to the soil have been drawn from the scientific results (Sedogo, 1993). Despite the attention given to this problem and the efforts made by most stakeholders, soil degradation continues to compromise the achievement of food security goals in sub-Saharan Africa. One of the causes of this soil degradation is the failure of farmers to comply with research recommendations. As a matter of fact, the recommended doses of mineral fertilizers and organic matter are far from being respected. The situation is further aggravated by the rapid mineralization of the applied organic matter to the soil (Sedogo, 1993). To address this critical issue, biochar is increasingly promoted as a new technology that can sustainably improve soil fertility while minimizing the negative impact of agriculture on the environment (Steiner et al, 2008; Wayne, 2012). Biochar is a by-product of pyrolysis, which is a carbonization process that captures the gaseous effluents resulting from the heat transformation of different types of biomass (Lehmann, 2007). It has very remarkable properties both agronomically and environmentally. Biochar incorporated into the soil persists longer and adsorbs cations better than other types of organic amendments (Lehmann et al, 2006; Lehmann, 2007, Mahmoud et al, 2018). The use of biochar as an amendment improves soil fertility and crop yields (Steiner et al, 2008; Glaser et al, 2002). It contributes to sequester carbon into the soil and improves soil properties to reduce greenhouse gas emissions (Lehmann, 2007; Laird et al, 2010; Collet and Rousseau, 2015; Naisse, 2015). Other studies show a beneficial effect of biochar on soil fertility and plant productivity when combined with fertilizer or manure (Novak et al, 2009; Badji, 2011; Xu et al, 2012; 
Manka'abusi et al, 2019; Akoto-Danso et al, 2019; Lompo et al, 2020).

Biochar can be produced using different types of reactors including locally manufactured reactors and modern ones (International Biochar Initiative (IBI), 2013); Jeguirim and Limousy, 2017). Local reactor models allow for the production of biochar in batch mode that is in small piles of biomass, as opposed to modern reactors that produce biochar continuously. Local reactors are simple to manufacture, less expensive, and allow clean combustion. They are suitable for small farmers because they allow the production of biochar from crop residues and production can reach $1000 \mathrm{~kg}$ per day (Anderson, 2013; IBI, 2013).

Biochar can be produced with any kind of plant biomass. However, the quantity and quality of biochar depend on several factors such as the type of raw material used (Singh et al, 2010; $\mathrm{Wu}$ et al, 2012). Indeed, the characteristics of biochar vary much more with the type of biomass used for its production and therefore have different effects on soil properties (Schimmelpfennig and Glaser, 2012). Therefore, the characterization of biochars resulting from the pyrolysis of different feedstock is necessary to adapt the types of biochar suitable for a particular soil type. In Burkina Faso, little is known about biochar technology and scientific research on biochar production and characterization is almost non-existent. The present study was initiated in this framework to produce and characterize biochar from crop residues available in Burkina Faso.

\section{Material and Method}

\subsection{Study Sites}

The study was conducted in the INERA research station, Farako-Bâ, Burkina Faso. This research station is about 10 kilometers south of Bobo-Dioulasso and covers an area of 475 hectares. The INERA-Farako-Bâ research station is located at $04^{\circ} 20^{\prime}$ West longitude and $11^{\circ}$ 06' North latitude with an altitude of 505 meters above sea level.

\subsection{Biomass Types}

Three types of crop residues were used which included cotton stems, corn cobs and sorghum stems. These crop residues are available in Burkina Faso, particularly in the western and south-western zones. Also, apart from sorghum stems, cotton stems and corn cobs are so far scarcely or not at all used for animal feed and firewood. Cotton stems are most often burned in the fields during soil preparation while corn cobs are usually discarded or burned by women to collect the ash for potash.

Crop residues were collected in farmer fields and stored in the open air for drying. The cotton and sorghum stems were cut into small pieces of 10 to $15 \mathrm{~cm}$ and corn cobs were used without further modification.

\subsection{Type of Reactor}

The type of reactor used in this study was a local cone kiln made from a 200-liter barrel (Anderson, 2013). This type of kiln is essentially made up of three components: a column or barrel with a perforated bottom and a cut-out upper rim, a cone-shaped lid, and a chimney of 


\section{Ml Macrothink}

$20 \mathrm{~cm}$. These components properly put together as shown in Figure 1 allow good air circulation through the reactor from bottom to top (Anderson, 2013; Frogner and Clayton, 2013). Five cone reactors were locally made for this study.

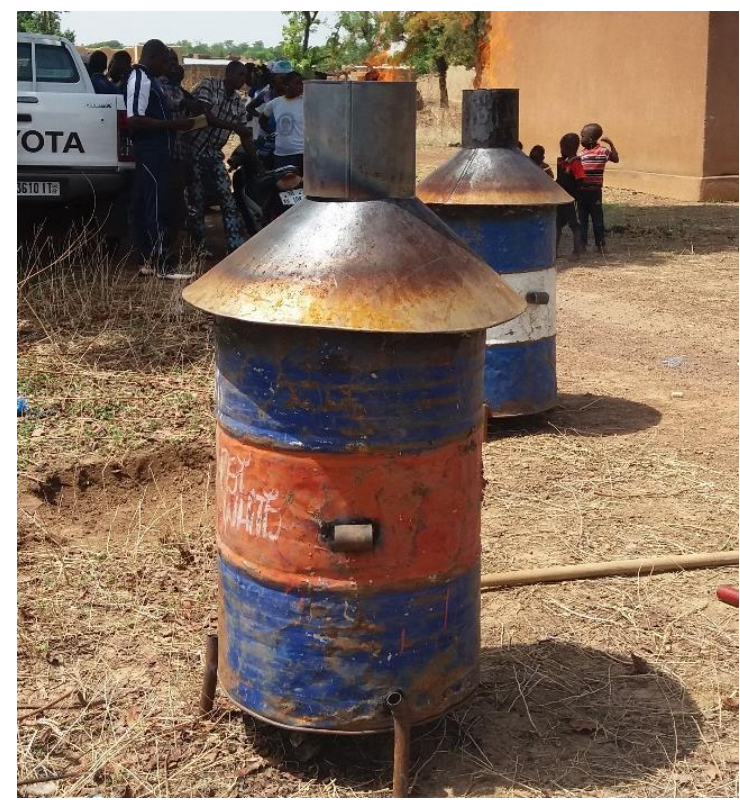

Figure 1. Type of reactor used in this study: a cone kiln model

This type of kiln allows incandescent pyrolysis or flame pyrolysis to be carried out with a low oxygen supply. The column is filled with dry biomass that is ignited from the top. This fire, deprived of oxygen, heats the underlying biomass leading to the production of pyrolytic gases. The pyrolytic gases move upwards due to a flux air coming from the bottom of the perforated column. These upwardly displaced gases burn and form a clean, smokeless flame due to a second air flux that enters the kiln at the tears located at the upper edge of the column. The dry biomass is thus gradually pyrolyzed from top to bottom (Anderson, 2013).

\subsection{Biochar Production Procedure}

$10 \mathrm{~kg}$ of each type of residue was introduced into a reactor in five replicates. The production was made in three steps.

Step 1: The biomass introduction into the kiln. The biomass was carefully introduced without too much compression to allow air circulation. The stems were placed vertically inside the kiln whereas the corn cobs were placed in bulk;

Step 2: The activation of the combustion and carbonization itself. Activation of the carbonization was done by using an easily flammable straw that had been placed above the biomass previously put in the kiln. The charring had already started with the ignition of the activator. The ovens were then closed with their lids to limit the entry of air. At each furnace, the chimneys were placed last to channel the flames. The carbonization was thus carried out from top to bottom until the biomass at the bottom of the furnace was reached.

Step 3. It consisted of stopping the combustion. The charring process was stopped when all 
the biomass introduced into the kiln had been charred. To know this, straw had been deposited on the ground under de kiln at the beginning of the carbonization. This straw burned when the biomass at the bottom of the kiln was charred. To stop the charring process the embers that is the biochar were turned over and immediately sprinkled with water to prevent them from turning into ash. The produced biochars were weighed and then dried in the open air.

\subsection{Biochar Production Parameters}

The measured production parameters included the pyrolysis duration (PD), the biochar quantity (BQ), and the biochar production yield (BY). The pyrolysis duration (PD) was measured by recording the start and end times of pyrolysis and using formula (1) to calculate it.

$$
\mathrm{PD}(\mathrm{mn})=(\text { Hend }- \text { Hstart }) \times 60
$$

Where: PD = Pyrolysis duration in minutes;

Hstart = pyrolysis start time;

Hend: pyrolysis end time.

The biochar quantities (BQ, fresh weight) were determined by weighing the biochar at the end of the pyrolysis process. The pyrolysis yields (PY) were determined using formula (2).

$$
\mathrm{PY}(\%)=\mathrm{BQ} / \mathrm{RQ} \times 100
$$

Where: $\mathrm{BQ}=$ biochar quantity ;

$\mathrm{RQ}=$ residue quantity.

\subsection{Chemical Analysis of Biochars}

The $\mathrm{pH}$ of the biochars were determined using a glass electrode $\mathrm{pH}$ meter with a biochar/solution ratio of 1/2.5 (McLean, 1982). Total nitrogen (total N), total phosphorus (total $\mathrm{P}$ ) and potassium (total $\mathrm{K}$ ) were extracted by digestion in a complex of sulphuric acid, salicylic acid, hydrogen peroxide, and selenium. The determination of nitrogen was carried out by the micro-KJELDAHL method. Total phosphorus was determined calorimetrically using the molybdo-phosphate reduced ascorbic acid method. Potassium was determined by flame emission spectrophotometry (BUNASOLS, 1987). The organic matter content of the biochar was determined using the loss on ignition method by calcination at $650^{\circ} \mathrm{C}$. The organic matter (OM) and organic carbon (Corg) contents were calculated with formulae (3) and (4), respectively (Bell, 1964; Conseil des Productions Végétales du Québec, 1988).

$$
\mathrm{OM}(\%)=((\mathrm{PC}+\mathrm{E})-\mathrm{P} 650) /((\mathrm{PC}+\mathrm{E})-\mathrm{PCv}) \times 100
$$

Where :

$\mathrm{OM}=$ organic matter in $\%$.

$\mathrm{PC}=$ dome and sample weight 
$\mathrm{P} 650=$ weight of the dome and sample after calcination in the furnace at $650^{\circ} \mathrm{C}$

$\mathrm{PCV}=$ weight of the empty dome

$$
\operatorname{Corg}(\%)=\mathrm{MO} / 1.7274
$$

Where:

Corg $=$ organic carbon

$\mathrm{OM}=$ Organic matter content

The exchangeable cations $\mathrm{Ca}^{2+}, \mathrm{K}^{+}, \mathrm{Na}^{+}, \mathrm{Mg}^{2+}$ contained in the biochar were displaced by a solution of silver thiourea $\left[\mathrm{Ag}\left(\mathrm{H}_{2} \mathrm{NCSNH}_{2}\right)_{2}{ }^{+2}\right] . \mathrm{Ca}^{2+}$ and $\mathrm{Mg}^{2+}$ were determined by atomic absorption spectrophotometry and $\mathrm{K}^{+}$and $\mathrm{Na}^{+}$by flame photometry (BUNASOLS, 1987). The trace elements $\mathrm{Cu}, \mathrm{Fe}$ and $\mathrm{Zn}$ were determined by the dry calcination mineralization method. The ashes obtained are first treated with $1 \mathrm{~N}$ nitric acid $\mathrm{HNO}_{3}$. After passing through a muffle oven at $673 \mathrm{~K}$, the ash was re-dried a second time with $1 \mathrm{~N}$ hydrochloric acid $(\mathrm{HCl})$. The extraction was done with $0.1 \mathrm{~N} \mathrm{HCl}$ and the determinations of $\mathrm{Cu}, \mathrm{Fe}$ and $\mathrm{Zn}$ were obtained by atomic absorption spectrophotometry (Pinta, 1972).

\subsection{Statistical Analysis}

The data were analyzed using IBM SPSS Statistics 22 software (IBM Corporation, Armonk, NY, USA). Data normality tests were performed using the Shapiro-Wilk method. An analysis of variance using the general linear model was performed when the data were normally distributed, and the mean comparisons were performed using the Tukey method. Non-parametric tests were performed for parameters where the data were not normally distributed using the Kruskal-Wallis multiple comparison test for the mean separations.

\section{Results}

\subsection{Variation of Biochar Production Durations According to the Type of Biomass}

The differences in biochar production durations were very highly significant $(\mathrm{p}<0.000)$. The highest average value of residence time was obtained with corn cobs. The pyrolysis durations of cotton and sorghum stems were statistically equivalent (Table 1).

Table 1. Variation of biochar production duration according to the type of crop residues. Each value represents the mean value $(n=5)$ followed by one standard error of the mean in brackets

\begin{tabular}{lc}
\hline Crop residue & Pyrolysis duration $(\mathrm{mn})$ \\
\hline Corn cobs & $37(1.5) \mathrm{a}$ \\
Cotton stems & $23(1.8) \mathrm{b}$ \\
Sorghum stems & $20(1.3) \mathrm{b}$ \\
\hline $\mathrm{P}(5 \%)$ & 0.000 \\
\hline Significance & VHS \\
\hline
\end{tabular}

Means followed by the same letter do not differ significantly according to Tukey method at the $5 \%$ probability $(\mathrm{P})$ threshold; VHS=very highly significant. 
3.2 Variation of the Biochar Quantity and the Production Yield According to Crop Residue Types

The biochar quantity was affected by the crop residue type. The amounts of biochar obtained from cotton stems and corn cobs were equivalent ( $>0.05)$ but significantly higher than the amount of sorghum derived-biochar $(\mathrm{P}<0.05)$. The same trends were observed for biochar production yields (Table 2).

Table 2. Variation of biochar quantity and the production yield according to crop residue types. Each value represents the mean value $(n=5)$ followed by one standard error of the mean in brackets

\begin{tabular}{lcc}
\hline \multicolumn{1}{c}{ Crop residue } & $\begin{array}{c}\text { Biochar quantity } \\
(\mathrm{kg})\end{array}$ & $\begin{array}{c}\text { Production yield } \\
(\%)\end{array}$ \\
\hline Corn cobs & $3.1(0.29) \mathrm{a}$ & $31(2.92) \mathrm{a}$ \\
Cotton stems & $3.3(0.30) \mathrm{a}$ & $33(3.00) \mathrm{a}$ \\
Sorghum stems & $1.8(0.12) \mathrm{b}$ & $18(1.23) \mathrm{b}$ \\
\hline \multicolumn{1}{c}{ P $(\%)$} & 0.0001 & 0.0001 \\
Significance & VHS & VHS \\
\hline
\end{tabular}

Means followed by the same letter within the same column do not differ significantly at the $5 \%$ probability $(\mathrm{P})$ threshold; VHS=very highly significant.

3.3 Variation of Biochar Corg, OM, C/N and pH Levels According to the Type of Crop Residues

The Corg contents of biochar varied significantly between $31 \%$ and $51 \%$ depending on the type of crop residue. The highest level of Corg (51\%) was obtained with corn cobs, followed by cotton stems. The lowest level of Corg was obtained with sorghum stems. The same trend was observed in the $\mathrm{OM}$ of biochars. The highest $\mathrm{C} / \mathrm{N}(\mathrm{p}<0.05)$ was recorded with biochar from corn cobs. Biochars obtained from cotton stems and sorghum stems had statistically equivalent $\mathrm{C} / \mathrm{N}$ values $(\mathrm{p}>0.05)$. The $\mathrm{C} / \mathrm{N}$ values for the three types of biochar ranged from 41 to 88. Significant differences were also observed between the $\mathrm{pH}$ values of the produced biochars, which ranged from 7.8 to 10 . The highest $\mathrm{pH}$ value was recorded with the corn cobs derived biochar followed by sorghum stems-based biochar which was higher $(\mathrm{p}<0.05)$ than the $\mathrm{pH}$ value of the cotton stems-derived biochar (Table 3). 
Table 3. Variation of biochar Corg, $\mathrm{OM}, \mathrm{C} / \mathrm{N}$ and $\mathrm{pH}$ levels according to the type of crop residues. Each value represents the mean value $(n=5)$ followed by one standard error of the mean in brackets

\begin{tabular}{|c|c|c|c|c|}
\hline \multirow{2}{*}{ Crop residue } & Corg & $\mathrm{OM}$ & $\mathrm{C} / \mathrm{N}$ & $\mathrm{pH}$ \\
\hline & \multicolumn{2}{|c|}{$\%$} & & \\
\hline Corn cobs & $50.97(0.270) \mathrm{a}$ & $87.80(0.583) \mathrm{a}$ & $88.20(0.490) \mathrm{a}$ & $10.0(0.02) \mathrm{a}$ \\
\hline Cotton stems & $49.42(0,268) b$ & $85.20(0.374) b$ & $69.40(4.366) b$ & $9.4(0.06) \mathrm{c}$ \\
\hline Sorghum stems & $31.49(0.187) \mathrm{c}$ & $54.40(0.245) \mathrm{c}$ & $63.20(3.734) b$ & $9.7(0.03) b$ \\
\hline$P(5 \%)$ & 0.000 & 0.000 & 0.000 & 0.000 \\
\hline Significance & VHS & VHS & VHS & VHS \\
\hline
\end{tabular}

Means followed by the same letter within the same column do not differ significantly at the $5 \%$ probability $(\mathrm{P})$ threshold; VHS=very highly significant.

\subsection{Variation of Biochar Nutrient Contents According to the Type of Crop Residue}

The total $\mathrm{N}$ and total $\mathrm{P}$ contents of the three types of biochar were between $0.50 \%$ and $1.0 \%$ and $0.52 \mathrm{mg} . \mathrm{kg}^{-1}$ and $2.61 \mathrm{mg} . \mathrm{kg}^{-1}$, respectively. The cotton stems and corn cobs biochars had identical levels of total $\mathrm{N}$. The biochar derived from corn cobs had a higher total $\mathrm{P}$ content as compared to the cotton stems-derived biochar (Table 4).

Table 4. Variation of biochar nutrient contents according to the type of crop residue. Each value represents the mean value $(n=5)$ followed by one standard error of the mean in brackets

\begin{tabular}{|c|c|c|c|c|c|c|}
\hline \multirow{2}{*}{ Type of biomass } & $\mathrm{N}$ total & $\mathrm{P}$ total & $\mathrm{K}$ total & $\mathrm{Na}$ & $\mathrm{Ca}$ & $\mathrm{Mg}$ \\
\hline & $\%$ & \multicolumn{3}{|c|}{----1 } & \multicolumn{2}{|c|}{------------g.kg-1----------- } \\
\hline Corn & $0.68(0.069) \mathrm{ab}$ & $1.54(0.081) \mathrm{a}$ & $18.67(0.568) b$ & $0.32(0.148) \mathrm{ab}$ & $1.37(0.108) \mathrm{c}$ & $1.26(0.052) \mathrm{c}$ \\
\hline Cott & $0.72(0.046) \mathrm{a}$ & 1.03 & 32.47 & $0.46(0.075) \mathrm{a}$ & $10.32(0.254) b$ & $4.78(0.087) b$ \\
\hline Sorghum & $0.52(0.037) \mathrm{b}$ & $1.33(0.060) \mathrm{a}$ & $20.06(0.531) \mathrm{b}$ & $0.08(0.009) \mathrm{b}$ & $11.88(0.346) \mathrm{a}$ & $6.58(0.161) \mathrm{a}$ \\
\hline $\mathrm{P}(5 \%)$ & 0.000 & 0.000 & 0.000 & 0.000 & 0.000 & 0.000 \\
\hline Significance & VHS & VHS & VHS & VHS & VHS & VHS \\
\hline
\end{tabular}

Means followed by the same letter within the same column do not differ significantly at the $5 \%$ probability $(\mathrm{P})$ threshold; VHS=very highly significant.

\subsection{Variation of Biochar Heavy Metal Contents According to the Type of Crop Residue}

The sorghum stems biochar had the highest $\mathrm{Cu}$ content $(\mathrm{p}<0.05)$ followed by the corn cobs biochar. The lowest $\mathrm{Cu}$ content was registered in the cotton stem biochar. The $\mathrm{Cu}$ levels ranged from $0.56 \mathrm{mg} \cdot \mathrm{kg}^{-1}$ to $23.36 \mathrm{mg} \cdot \mathrm{kg}^{-1}$. The highest $\mathrm{Fe}$ content was obtained with sorghum stem biochar $(\mathrm{p}<0.05)$ and the lowest with cotton stem biochar $(\mathrm{p}<0.05)$. The Fe 
contents of the biochars varied between $1.95 \mathrm{mg} \cdot \mathrm{kg}^{-1}$ and $6.96 \mathrm{mg} \cdot \mathrm{kg}^{-1}$. For $\mathrm{Zn}$, the corn cobs biochar had the highest content $(\mathrm{p}<0.05)$ followed by sorghum stems biochar $(\mathrm{p}<0.05)$. The $\mathrm{Zn}$ contents of the three biochars fluctuated between $25.64 \mathrm{mg} \cdot \mathrm{kg}^{-1}$ and $111.66 \mathrm{mg} \cdot \mathrm{kg}^{-1}$ (Table $5)$.

Table 5. Variation of biochar heavy metal contents according to the type of crop residue. Each value represents the mean value $(n=5)$ followed by one standard error of the mean in brackets

\begin{tabular}{lccc}
\hline \multirow{2}{*}{ Type de Biomasse } & $\mathrm{Cu}$ & $\mathrm{Fe}$ & $\mathrm{Zn}$ \\
\cline { 2 - 4 } & \multicolumn{3}{c}{${\mathrm{mg} \cdot \mathrm{kg}^{-1}}$} \\
\hline Corn cobs & $12.37(0.127) \mathrm{b}$ & $5.39(0.307) \mathrm{b}$ & $111.66(0.708) \mathrm{a}$ \\
Cotton stems & $0.56(0.129) \mathrm{c}$ & $1.95(0.057) \mathrm{c}$ & $25.64(2.510) \mathrm{c}$ \\
Sorghum stems & $23.36(1.196) \mathrm{a}$ & $6.96(0.431) \mathrm{a}$ & $106.03(0.711) \mathrm{b}$ \\
\hline $\mathrm{P}(5 \%)$ & 0.000 & 0.000 & 0.000 \\
\hline Significance & VHS & VHS & VHS \\
\hline
\end{tabular}

Means followed by the same letter within the same column do not differ significantly at the $5 \%$ probability $(\mathrm{P})$ threshold; VHS=very highly significant.

\section{Discussion}

\subsection{Effects of Biomass Types on the Pyrolysis Duration}

The pyrolysis duration varies according to the type of crop residue. This is due to the lignin content which differs from one type of residue to another. The higher the lignin content the longer the pyrolysis duration (Demirbas, 2006). The duration of charring depends on the size of the biomass fragments, which influences the air circulation in the kiln. As the corn cobs piled up in the kiln it reduced the airflow and thus the pyrolysis speed. This therefore resulted in an extension of the residence time of the corn cobs in the kiln.

\subsection{Effects of Biomass Types on the Amount of the Produced Biochar, and the Production Yield}

The differences in the lignin content of the different biomasses led to differences in the pyrolysis duration, the amount of the produced biochar and the pyrolysis yield (Demirbas, 2006). The same results were previously reported by Jindo et al, (2014) who found some incorporated silica elements into the chemical structure of rice husks.

\subsection{Effects of Biomass Types on Biochar Corg, OM Contents, C/N and pH}

The Corg content of biochar varied significantly according to the type of biomass and the same trend was observed for the OM in the biochars. Similar results were reported by Laghari et al, (2016) who indicated that biomass types induce different levels of Corg or nutrients. The Corg contents (31\% to 51\%) of the biochar produced in this study is in accordance with the standards of International Biochar Initiative (IBI, 2012) and the European Biochar Certificate (EBC, 2012). This implies that the three studied crop residues are suitable for biochar production as the resulting biochars meet the recommended criteria. The $\mathrm{C} / \mathrm{N}$ ratios 
ranged from 41 to 88 for the three types of biochars produced and corroborates Bruun et al, (2012) who observed similar values. These high $\mathrm{C} / \mathrm{N}$ values could lead to soil nitrogen immobilization (Kanouo, 2017) which could compromise good plant development if the use of this biochars is not combined with nitrogen fertilizers. The $\mathrm{pH}$ values of the three types of biochar are between 7.8 and 10 and are in line with those reported by most of the studies carried out on biochar (Laghari et al, 2016). Similar results were recorded by Singh et al, (2010) with tomato-derived biochar. According to Domingues et al, (2017) these high pH values of biochar are explained by their high ash content which enriches the biochar with compounds such as $\mathrm{KHCO}_{3}$ and $\mathrm{CaCO}_{3}$ with important alkalizing capacities. Indeed, Yuan et al, (2011a) had previously shown that carbonates are the main alkalizing compounds in biochar. The high and different $\mathrm{pH}$ values of the three types of biochar produced in the current study revealed their abilities to correct the $\mathrm{pH}$ of acidic soils at different levels (Domingues et al, 2017). Considering this, the use of these biochars with high $\mathrm{pH}$ values is an interesting alternative for raising the $\mathrm{pH}$ values of acidic soils in Burkina Faso and the other Sahelian countries.

\subsection{Effects of Biomass Types on the Biochar Nutrient Contents}

The nutrient contents of the biochars varied according to the type of crop residue. Similar results were observed by Singh et al, (2010); Wu et al, (2012). According to previous studies conducted by Zhao et al, (2013) and Laghari et al, (2016) on the pyrolysis of different types of biomass, the characteristics of the biomass including the yield of biochar, Corg content, nutrient content and $\mathrm{pH}$ vary according to the type of biomass. The levels of total $\mathrm{N}$, total $\mathrm{P}$, total $\mathrm{K}$ and $\mathrm{Na}$ were low and are consistent with those of Slavich et al, (2013) who found that biochars obtained from crop residues have low content in plant nutrients. However, the same authors have revealed that some biochars derived from crop residues (canola, rice and pea straw) can have high nutrient contents, particularly $\mathrm{P}$ and $\mathrm{K}$. The chemical compositions of the biochar depended on the type of biomass but also on the pyrolysis temperature (Yuan et al, 2011b). According to Al-Wabel et al, (2013), the higher the pyrolysis temperature is, the higher the nutrient contents of the biochar are. However, pyrolysis temperatures above $700^{\circ} \mathrm{C}$ can lead to $\mathrm{P}$ and $\mathrm{K}$ losses from the biochar (Laghari et al, 2015). Unfortunately, the pyrolysis temperatures were not measured in this study due to the lack of adequate temperature meters. Taking into account the high $\mathrm{C} / \mathrm{N}$ of the three Biochars produced in this study, it is clear that their use as an amendment must be associated with mineral fertilizers to ensure good plant development and crop yields.

\subsection{Effects of Biomass Type on the Heavy Metal Content of Biochars}

The biochars $\mathrm{Cu}$ contents varied from one type of crop residue to one another and the levels (from $0.56 \mathrm{mg} . \mathrm{kg}^{-1}$ to $23.36 \mathrm{mg} \cdot \mathrm{kg}^{-1}$ ) were consistent with those reported by Luo et al, (2014) for corn residues (from 20.4-56.7 mg. $\mathrm{kg}^{-1}$ ). The Fe content of the biochar varied between 1.95 and $6.96 \mathrm{mg} . \mathrm{kg}^{-1}$ depending on the type of culture residue. López-Cano et al (2018) found $\mathrm{Fe}$ contents ranging from $0.0 \mathrm{mg} \cdot \mathrm{kg}^{-1}$ to $106.9 \mathrm{mg} \cdot \mathrm{kg}^{-1}$ in biochar from different biomass sources. The Fe content of the cotton stems biochar $\left(1.95 \mathrm{mg} \cdot \mathrm{kg}^{-1}\right)$ was consistent with those reported by Tan et al (2017). With respect to Zn, the contents of the three Biochars 
fluctuated between $25.64 \mathrm{mg} \cdot \mathrm{kg}^{-1}$ and $111.66 \mathrm{mg} \cdot \mathrm{kg}^{-1}$ and felt within the range of 0.94 $\mathrm{mg} \cdot \mathrm{kg}^{-1}$ to $207 \mathrm{mg} \cdot \mathrm{kg}^{-1}$ reported by Freddo et al (2012). Moreover, a recent study by Zhang et al (2018) also revealed that the $\mathrm{Zn}$ contents of different biomasses varied between 4.91 $\mathrm{mg} . \mathrm{kg}^{-1}$ and $173.50 \mathrm{mg} \cdot \mathrm{kg}^{-1}$. The three produced biochars from cotton stems, corn cobs and sorghum stems showed heavy metal contents which are in line with the international standards recommended for biochar by IBI (2012) and EBC (2012).

\subsection{Agronomic Implications of the Study}

The study revealed that the cone kiln reactor model was effective in producing biochar from the three types of crop residues considered in this study. This is valuable information for researchers and mostly for farmers in Burkina Faso who could now produce biochars as soil amendments from different crop residues instead of burning them during field preparations for sowing. The characteristics of the biochars produced depend strongly on the types of crop residues. Their use as agricultural amendments must take that into account to optimize their effectiveness. The produced biochars have alkaline $\mathrm{pH}$ and can be used to raise the $\mathrm{pH}$ of acidic soils, especially those of Sahelian countries whose $\mathrm{pH}$ values are generally very acidic $(4.2<\mathrm{pH}<5.0)$ and acidic $(5.0<\mathrm{pH}<6.5$; Brady and Weil, 2008, Koulibaly et al, 2014). The nutrient contents of the three biochars produced are low, but their carbon contents are very good. Therefore, they should be used mainly for amendment purposes. Considering their high $\mathrm{C} / \mathrm{N}$, it is clear that their use as soil improvers must be combined with mineral fertilizers to ensure good plant development and therefore good agricultural yields.

\section{Conclusion}

The results achieved in this study indicate clearly that the cone kiln model is suitable for biochar production from different crop residues. The production yields obtained using a locally made reactor are related to the type of crop residue and meet the international standards. Moreover, the chemical characteristics of the produced biochars are crop residue-related and they are agronomically interesting. Because of their high $\mathrm{C} / \mathrm{N}$, these three biochars can be used as soil amendments but with the addition of mineral fertilizers. These biochars can buffer soils $\mathrm{pH}$ at different levels. In a context of climate change combined with poor soil fertility and low agricultural yields in Burkina Faso, the production and the use of biochar is a promising tool for a better valorization of crop residues improved soil fertility. Future investigations are needed with a focus on the opportunities and the risks related to the use of crop residues for producing biochar as soil amendments.

\section{References}

Akoto-Danso, E. K., Manka'abusi, D., Steiner, C., Werner, S., Haering, V., Lompo, D. J. P., ... Buerkert, A., (2019). Nutrient flows and balances in intensively managed vegetable production of two West African cities. Journal of plant nutrition and soil science, 1-15. https://doi.org/10.1002/jpln.201800339

Al-Wabel, M. I., Al-Omran, A., El-Naggar, A. H., Nadeem, M., \& Usman, A. R. (2013). Pyrolysis temperature induced changes in characteristics and chemical composition of biochar produced from conocarpus wastes. Bioresour Technol 131, 374-379. https://doi.org/10.1016/j.biortech.2012.12.165 
Anderson, P. S. (2013). Affordable Biochar Production Options Small Cookstoves, Medium Barrels, and Some Large Devices. Presentation to First Midwest Biochar Conference, 14 June 2013, Champaign, IL. 50p. http://www.biochar.illinois.edu

Badji, A. (2011). Effet du biochar sur les activités microbiologiques du sol sous forts intrants azotés (maraîchage), mémoire pour l'obtention du Master II en Biologie Végétale et Microbienne, Université Cheikh Anta Diop de Dakar, Faculté des sciences et Techniques, département de Biologie Végétale, 48p.

https://pdfslide.fr/documents/effets-du-bio-char-sur-les-activites-micro-biologiques-du-sol-so us-forts-.html

Bell, D. F. (1964). Loss-on-ignition as an estimate of organic matter and organic carbon in non-calcareous soils, Journal of Soil Science, 15, 84-92.

https://doi.org/10.1111/j.1365-2389.1964.tb00247.x

Bikienga, I. M. (2002). Une évaluation des secteurs des Engrais et des Semences au Burkina Faso. ATRIP: the African Trade Investment Program Policy Reform to Enhance Trade of Agricultural Inputs in West Africa, rapport de consultation, 31p. www.ifdc.org

Brady, N. C., \& Weil, R. R. (2008). The Nature and Properties of Soils. 14 ed., Pearson Prentice Hall, Upper Saddle River: NJ; 990 p

Bruun, E. W., Ambus, P., Egsgaard, H., \& Hauggaard-Nielsen, H. (2012). Effects of slow and fast pyrolysis biochar on soil C and N turnrover dynamics. Soil Biol Biochem, 46, 73-79. https://doi.org/10.1016/j.soilbio.2011.11.019

BUNASOLS, (1987). Méthode d'analyse physique et chimique des sols, eaux et plantes. Document technique, 3, 286p.

https://www.pearson.com/us/higher-education/product/Brady-Nature-and-Properties-of-SoilsThe-14th-Edition/9780132279383.html

Collet, S., \& Rousseau, A., (2015). Création d'une entreprise sociale visant à récupérer les sols dégradés au Burkina Faso à l'aide de techniques agro-écologiques innovantes. Mémoire Master, Spécialités Sciences de Gestion et Sciences et technologies de l'environnement, Louvain School of Management, Université catholique de Louvain, 84p. http://hdl.handle.net/2078.1/

Conseil des productions végétales du Québec, (1988). Détermination de la matière organique par incinération, Agdex 533, Méthode MA-2, 1 p.

Demirbas, A. (2006). Production and Characterization of Bio-Chars from Biomass via Pyrolysis. Energy Sources Part A: Recovery, Utilization \& Environmental Effects, 28, 413-422. https://doi.org/10.1080/009083190927895

Domingues, R. R., Trugilho, P. F., Silva, C. A., Melo, I. C. N. A. D, Melo, L. C. A., Magriotis, Z. M., \& Sanchez-Monedero, M. A. (2017). Properties of biochar derived from wood and high nutrient biomasses with the aim of agronomic and environmental benefits. PLOS ONE, 12(5). https://doi.org/10.1371/journal.pone.0176884

European Biochar Certificate, (2012). EBC Guidelines for a Sustainable Production of Biochar.' European Biochar Foundation (EBC), Arbaz, Switzerland. http://www.european-biochar.org/en/download. Version 6.2E of 04th February 2020, https://doi.org/210.13140/RG.2.1.4658.7043 
Freddo, A., Cai, C., \& Reid, B. (2012). Environmental contextualization of potential toxic elements and polycyclic. Environ. Pollut., 171, 18-24.

https://doi.org/10.1016/j.envpol.2012.07.009

Frogner, K., \& Clayton, D. (2013). Jolly Roger \& other Biochar Ovens. Communication presented à United States Biochar Initiaitive (USBI) Biochar conferences/ USBI North American Symposium, Harvesting hope: the science and synergies of biochar13-16 October 2013. https://scholarworks.umass.edu/biochar/2013/Production/2/

Glaser, B., Lehmann, J., \& Zech, W. (2002). Ameliorating physical and chemical properties of highly weathered soils in the tropics with charcoal-a review. Biology and Fertility, 534p. https://doi.org/10.1007/s00374-002-0466-4

IBI, (2013). Pyrolysis and Gasification of Biosolids to Produce Biochar. White Paper: 4p. www.biochar-international.org

International Biochar Initiative, (IBI, 2012). Standardized product definition and product testing guidelines for biochar that is used in soil. IBI biochar Standard, $47 \mathrm{p}$. https://www.climate-engineering.eu/single/international-biochar-initiative-ibi-hg-2012-standa rdized-product-definition-and-product-testing-guidelines-for-biochar-that-is-.html

Jeguirim, M., \& Limousy, L. (2017). Biomass Chars: Elaboration, Characterization and Applications. Energies, 10, 2040, 1-10. https://doi.org/10.3390/en10122040

Jindo, K., Mizumoto, H., Sawada, Y., Sanchez-Monedero, M. A., \& Sonoki, T., (2014). Physical and chemical characterization of biochars derived from different agricultural residues. Biogeosciences, 11, 6613-6621. https://doi.org/10.5194/bg-11-6613-2014

Kanouo, B. M. D. (2017). Production et utilisation du biochar pour l'amendement des sols rouges lessivés tropicaux. Thèse de Doctorat en sciences forestières, Université de Laval, Québec, Canada, 118p. http://hdl.handle.net/20.500.11794/28120

Koulibaly B., Traoré O., Dakuo D., Lalsaga R., Lompo F., \& Zombre P. N. (2014). Acidification des sols ferrugineux et ferrallitiques dans les systèmes dproduction cotonnière au Burkina Faso. Int. J. Biol. Chem. Sci., 8(6), 2879-2890.

https://doi.org/10.4314/ijbcs.v8i6.44

Kumwenda, J. D. T., SWaddington, R., Snapp S. S., Jones, R. B., \& Blackie, M. J. (1996). Soil Fertility Management Research for the Maize Cropping Systems of Smallholders in Southern Africa: A Review. NRG Paper, 96-02.

https://repository.cimmyt.org/handle/10883/531

Laghari, M., Hu, Z., Mirjat, M. S., Xiao, B., Tagar, A. A., \& Hu, M. (2015). Fast pyrolysis biochar from sawdust improves the quality of desert soils and enhances plant growth. $J$ Sci Food Agric., 96,199-206. https://doi.org/10.1002/jsfa.7082

Laghari, M., Naidu, R., Xiao, B., Hu, Z., Saffar M., Hu, M., ... Fazal, S., (2016). Recent developments in biochar as an effective tool for agricultural soil management: a review. Journal of Science, Food and Agriculture, 96, 4840-4849. https://doi.org/10.1002/jsfa.7753

Laird, D. A., Fleming, P., Davis, D. D., Horton, R., Wang, B., \& Karlen, D. L. (2010). Impact of biochar amendments on the quality of a typical Midwestern agricultural soil. Geoderma, 158, (September), 443-449. https://doi.org/10.1016/j.geoderma.2010.05.013 
Lehmann, J. (2007). Bio-energy in the black. Frontiers in Ecology and the environment, 5, 381-387. https://doi.org/10.1890/1540-9295(2007)5[381:BITB]2.0.CO;2

Lehmann, J., Gaunt, J., \& Rondon, M., (2006). Bio-char sequestration in terrestrial ecosystems - a review. Mitigation and Adaptation Strategies for Global Change 11, 403-427. https://doi.org/10.1007/s11027-005-9006-5

Lompo, D. J. P., Balbone, A., Ye, L., \& Nacro, H. B. (2020). Effets du Biochar utilisé comme amendement sur les propriétés physico-chimiques des sols et les paramètres agronomiques du Sorgho dans la zone semi-aride du Burkina Faso. Science et technique, Sciences naturelles et appliquées, Spécial hors-série, 5, pp 387-398.

López-Cano, I., Luz Cayuela, M., Sánchez-García, M., \& Sánchez-Monedero, M. A. (2018). Suitability of Different Agricultural and Urban Organic Wastes as Feedstocks for the Production of Biochar-Part 2: Agronomical Evaluation as Soil Amendment. Sustainability 2018, 10, 2077. https://doi.org/10.3390/su10062077

Luo, F., Song, J., Xia, W., Dong, M., Chen, M., \& Soudek, P. (2014). Characterization of contaminants and evaluation of the suitability for land application of maize and sludge biochars. Environ. Sci. Pollut. Res. Int., 21(14), 8707-8717.

https://doi.org/10.1007/s11356-014-2797-8

Mahmoud, A. W. M., Elezaby, A. A., \& Hassan, A. Z. A. (2018). Evaluation of Uncommon Natural Fertilizers Resources for Grapevine Production Grown in Desert Soil. https://doi.org/10.5296/jas.v6i3.13284

Manka'abusi, D., Steiner, C., Akoto-Danso, E. K, Lompo, D. J. P., Haering, V., Werner, S., ... Buerkert, A. (2019). Biochar application and wastewater irrigation in urban vegetable production of Ouagadougou, Burkina Faso. Nutrient cycling in agroecosystems, https://doi.org/10.1007/s10705-019-09969-0(0123456789)

Mclean, E. O. (1982) Soil pH and Lime Requirement. In: Page, A. L., Ed., Methods of Soil Analysis. Part 2. Chemical and Microbiological Properties, American Society of Agronomy, Soil Science Society of America, Madison, 199-224.

https://doi.org/10.2134/agronmonogr9.2.2ed.c12

Naisse, C. (2015). Potentiel de séquestration de carbone de biochars et hydrochars, et impact après plusieurs siècles sur le fonctionnement du sol, thèse pour obtenir le Grade de Docteur en Sciences du sol et de l'environnement, Université Pierre et Marie Curie, Paris VI, Français. NNT: 2014PA066518, 114p. 〈NNT: 2014PA066518〉

Novak, J., lima, I., Xing, B., Gaskin, J. W., Steiner, C., Das, K., ... Schomberg, H. (2009). Caracterization of designed biochar produced at different temperatures and their effects on a loamy sand. Annals of Environnemental Science, 3, 195-206.

http://hdl.handle.net/2047/d10019637

Pinta M. (1972). Méthodes de référence pour la détermination des éléments minéraux dans les végétaux : détermination des éléments : calcium, magnésium, fer, manganèse, zinc et cuivre par absorption atomique. In : Contrôle de l'alimentation des plantes cultivées. Budapest (HON); s.l.: Académie des Sciences de Hongrie; CII, 1972, 143-158. http://horizon.documentation.ird.fr/exl-doc/pleins_textes/divers15-09/010039891.pdf

Schimmelpfennig, S., \& Glaser, B. (2012). One step forward toward characterization: Some important material properties to distinguish biochars. J. Environ. Qual., 41, 1001-1013. 
https://doi.org/10.2134/jeq2011.0146

2021, Vol. 9, No. 1

Sedogo, P. M. (1993). Evolution des sols ferrugineux lessivés sous culture/ incidence des modes de gestion sur la fertilité. Thèse de doctorat. Université de Cocody. Côte d'Ivoire, 285p.

Singh, B., Singh, B. P., \& Cowie, A. L. (2010). Characterization and evaluation of biochars for their application as a soil amendment. Australian Journal of Soil Research, 48, 516-525. https://doi.org/10.1071/SR10058

Slavich, P. G., Sinclair, K., Morris, S. G., Kimber, S. W. L., Downie, A., \& Van Zwieten, L. (2013). Contrasting effects of manure and green waste biochars on the properties of an acidic ferralsol and productivity of a subtropical pasture. Plant Soil, 366, 213-227. https://doi.org/10.1007/s11104-012-1412-3

Steiner, C., Das, K. C., Garcia, M., Förster, B., \& Zech, W. (2008). Charchoal and smoke extract stimulate the soil microbial community in a hihgly weathered xanthicferralsol. Pedologia, 51, p359-366. https://doi.org/10.1016/j.pedobi.2007.08.002

Tan, Z., Lin, C. S. K., Ji, X., \& Rainey, T. J. (2017). Returning biochar to fields: A review. Applied soil ecology, 116, 1-11. https://doi.org/10.1016/j.apsoil.2017.03.017

Wayne, E. (2012). Conquistadors, cannibials and climate change: a brief history of biochars. Innovation Towards Sustainable Development, Pro-Natura International, 5p. www.pronatura.org

Wu, W. X., Yang, M., Feng, Q. B., McGrouther, K., Wang, H. L., \& Lu, H. H. (2012). Chemical characterization of rice straw-derived biochar for soil amendment. Biomass Bioenergy, 47, 268-276. https://doi.org/10.1016/j.biombioe.2012.09.034

Xu, G., Lv., Y., Sun, J., Shao, H., \& Wel, L. (2012). Recent advences in biochar applications in agricultural soils: Benefits and environmental implications. Clean-Soil, Air, Water, 40, 1093-1098. https://doi.org/10.1002/clen.201100738

Yanggen, D., Kelly, V., Reardon, T., \& Naseem, A. (1998). Incentives for Fertilizer Use in Sub-Saharan Africa: A Review of Empirical Evidence on Fertilizer Response and Profitability. MSU International Development Working Papers, 80p

Yuan, J. H., Xu, R. K., \& Zhang, H. (2011b). The forms of alkalis in the biochar produced from crop residues at different temperatures. Bioresour. Technol., 102, 3488(97). https://doi.org/10.1016/j.biortech.2010.11.018

Yuan, J. H., Xu, R. K., Qian, W., \& Wang, R. H. (2011a). Comparison of the ameliorating effects on an acidic ultisol between four crop straws and their biochars. J. Soils Sediments, 11, 741-750. https://doi.org/10.1007/s11368-011-0365-0

Zhang, G., Zhihua, Z., Xiaofang, G., Zhiwang, H., Qiusheng, H., Fengsong, Z., \& Hongying, $X$. (2018). Levels of persistent toxic substances in different biochars and their potential ecological risk assessment. Environmental Science and Pollution Research, 25, 33207-33215. https://doi.org/10.1007/s11356-018-3280-8 


\section{Macrothink}

Journal of Agricultural Studies

ISSN 2166-0379 2021, Vol. 9, No. 1

Zhao, L., Cao, X., Masek, O., \& Zimmerman, A. (2013). Heterogeneity of biochar properties as a function of feedstock sources and production temperatures. J Hazard Mater 256-257, 1-9. https://doi.org/10.1016/j.jhazmat.2013.04.015

\section{Copyright Disclaimer}

Copyright for this article is retained by the author(s), with first publication rights granted to the journal.

This is an open-access article distributed under the terms and conditions of the Creative Commons Attribution license (http://creativecommons.org/licenses/by/4.0/). 